\title{
Protective effects of sulpiride treatment on kidney functions of female albino rats exposed to noise stress.
}

\author{
Eman G.Helal*, Fatma Eid**,Neama M.Taha. \\ Zoology Department ,Faculty of Science,Al-Azhar University. \\ ( Physiology*,Histology**)
}

\begin{abstract}
Background: Noise is the most stressful factor for experimental animals. So these studies aim to clarify its effect on some physiological and histological parameters.

Material and methods: 36 Female rats were divided into four groups (6/each):1-control, 2treated with sulpiride drug,3- noise exposure ( $90 \mathrm{db} / 3 \mathrm{~h}$ per day for 30days), 4-noise + drug

Results: drug recorded no significant change in all the studied parameters. Noise stress recorded a significant increase in creatinine, total lipids, TG, Cholesterol, HDL-C, LDL-C and no significant changes in urea, uric acide.

It has been detected that sulpiride drug ameliorated most of these parameters.Concerning the histological and histochemical studies sulpiride treatment showed no detectable changes in the kidney tissue with exception of increased lymphocytes. Exposure to noise showed many dystrophic changes in the kidney tissue, but drug treatment improved all the previous changes and this indicates the protective effect of sulpiride against noise exposure.
\end{abstract}

Conclusion: It is useful to use sulpiride drug in people who exposed to noise stress.

Key words: Noise,Sulpiride drug , Albino rats, Physiological parameters, Histopathalogy and histochemistery.

\section{Introduction}

Stress as noise is a part of everyone $\square \mathrm{s}$ life every day. From getting kids ready for school to fighting traffic to the demands of work, the average person goes up against the nemesis called stress multiple time daily .From waking up to sleeping our bodies are in a constant battle to maintain the balance. Noise is a kind of stresses which is defined as unwanted sound. Noise is a pervasive aspect of many modern community and work environments .Acute noise exposures activate the autonomic and hormonal systems, leading to temporary changes such as increased blood pressure, increased heart rate and vasoconstriction .After prolonged exposure, susceptible individuals in the general population may develop permanent effects, such as hypertension and ischemic heart disease that are associated with exposures to high sound pressure levels. (Tomoyuki, 2004).
According to Samson et al (2006) noise exposure over 90 decibel (db) becomes a stressor and contributes to the genesis and manifestation of several multifactor diseases, chronic annoyance and permanent behavioral alterations.

Antidepressant drugs are the most successful drug in patients with clearly characteristics including psychomotor retardation, sleep disturbance, poor appetite and weight loss. However, a variety of different chemical structures have been found to have antidepressant activity. Their number is constantly growing, but as yet no group has been found to have a clear therapeutic advantage over the others (Katzung, 2008). Sulpiride is the most favorite drug which used to tolerate stress symptoms (Panzani et al., 2011).

People exposed to stress take one or some drugs to avoid the effect of stress even without a doctor prescription. So, in this study we try in to illustrate the effect of 
one of the antidepressant drugs (sulpiride) which is generally used by people to avoid the effect of stress. The present study deals with the possible protective effect of sulpiride against noise in female albino rats from the physiological ,histological and histochemical points of view.

\section{Material and Methods}

\section{1-Experimental animals:}

36 Normal white female albino rats weighing ( $150 \pm 30)$ gms were taken from the farm of National organization for control and Research .They were kept under observation for one week before the beginning of the experiment to acclimatize .The chosen animals were housed in cages and exposed to artificial light for $14 \mathrm{hrs}$ and $10 \mathrm{hrs}$ complete darkness at normal atmospheric temperature .All animals were fed on standard diet contained protein ,fibers , fats ,ash, carbohydrates ,and supplied with vitamins and minerals mixture with continuous supply of water.

\section{2-Sulpiride administration:}

The drug was adiministrated orally by gastric tube at a dose of $0.28 \mathrm{mg} / 100 \mathrm{mg}$ body weigh/day for one month .The dose for the rat was calculated according to the Paget's formula on the basis of the human dose (Paget and Barns,1964)

\section{Methods:}

\section{(I) Animal groups:}

24 female albino rats were divided into 6 main groups each group contained 6 rats.

Group1: Normal rats served as negative control (without any treatment for one month).

Group 2: Rats treated with the sulpiride drug at dose of $(0.28 \mathrm{mg} / 100 \mathrm{mg}$ body weigh/day for one month).

Group 3: Rats exposed to noise only for one month over $90 \mathrm{~dB}, 3 \mathrm{~h} / \mathrm{day}$.
Group 4 : Rats exposed to noise and treated with the drug for one month.

\section{a)Application of noise:}

Prepared Noise was applied by 5 different sources of unharmonic and high intensity music.

\section{Physiological studies:}

Serum urea and creatinine were measured according to the method of Junge $\boldsymbol{e t}$ al.(2004), serum uric acid was done using the method of Tietz (2006). Total lipid concentration was done according to the method of Knight et al.(1972),serum cholesterol level was measured according to the method of Tietz ( 1995),serum Triglycerides(TG) was done according to the method of Stein and Myers(1995), serum HDL-cholesterol and LDL-C were measured according to method of Sugiuchi (2005).

\section{Data analysis:}

The obtained results were statistically analyzed by using the student ( $\mathrm{T}$ test) according to the method of Snedecor and Cochran (1980)., $\quad \mathrm{P}<0.05 \quad$ considerd significant while $\quad \mathrm{P}<0.01$ highly significant.

\section{Histological and histochmical studies:}

Rats from control and treated groups were sacrificed after month and small pieces of kidney was taken for the histological and histochemical studies .Small pieces of kidney was fixed in $10 \%$ neutral buffered forml solution and Carnoy's fluid for the histological and histochemical studies .Paraffin section were prepared $5 \mu \mathrm{m}$ thickness and stained with Harris haematoxylin and eosin (Drury and Wallington, 1980). Proteins were detected by mercuric bromophenol blue method (Mazia et al.,1953).Polysaccharides were detected by PAS (periodic acSchiff)method (Pearse,1977).Mallory's trichome stain for demonstrating collagen fibers (Pearse, 1977). 


\section{Results}

Uric acid and Urea no significant change were recorded in all groups (table 1.2).

Table (1): serum Uric acid(mg/dl) in female albino rats after exposure to stress (noise) sulpiride, dual effect.

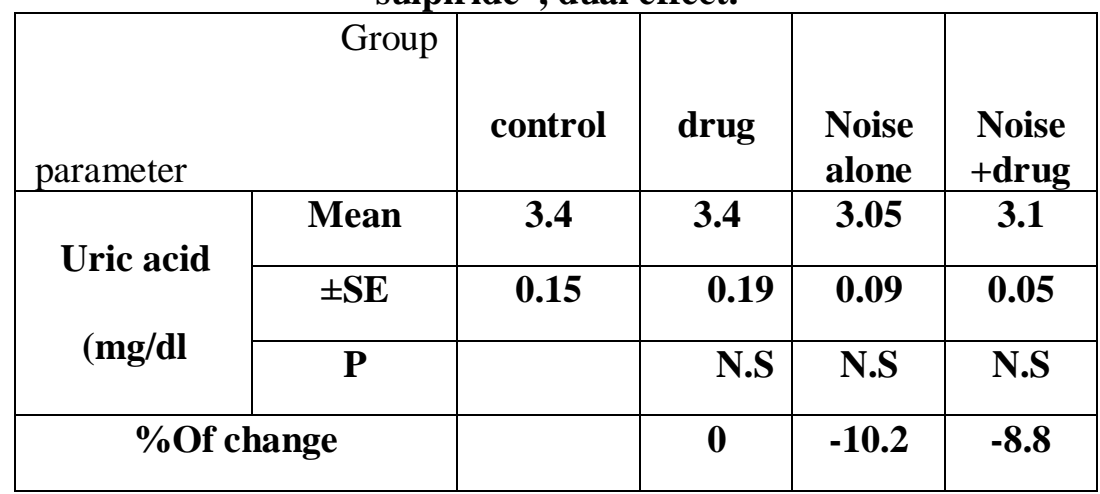

Table (2): serum Urea level (mg/dl) in female albino rats after exposure to stress (noise) sulpiride, dual effect.

\begin{tabular}{|c|c|c|c|c|c|}
\hline \multicolumn{2}{|c|}{ Group } & control & drug & $\begin{array}{c}\text { Noise } \\
\text { alone }\end{array}$ & $\begin{array}{c}\text { Noise } \\
\text { +drug }\end{array}$ \\
\hline parameter & Mean & 28.7 & 28.7 & 26.1 & 27.2 \\
\hline \multirow{2}{*}{$\begin{array}{c}\text { Urea } \\
(\mathrm{mg} / \mathrm{dl}\end{array}$} & \pm SE & 1.5 & 1.2 & 1.6 & 1.7 \\
\cline { 2 - 6 } & P & & N.S & N.S & N.S \\
\cline { 2 - 6 } & \%Of change & & 0 & -9.0 & -5.2 \\
\hline \multicolumn{2}{|c|}{$\%$} \\
\hline
\end{tabular}

Table (3): serum Creatinine level (mg/dl)in female albino rats after exposure to stress (noise) sulpiride , dual effect.

\begin{tabular}{|c|c|c|c|c|c|}
\hline \multicolumn{6}{|c|}{ Groun } \\
\hline \multicolumn{2}{|l|}{ parameter } & control & drug & $\begin{array}{l}\text { Noise } \\
\text { alone }\end{array}$ & $\begin{array}{l}\text { Noise } \\
+ \text { drug }\end{array}$ \\
\hline \multirow{3}{*}{$\begin{array}{c}\text { Creatinine } \\
\text { (mg/dl }\end{array}$} & Mean & 0.55 & 0.48 & 1.9 & 1.7 \\
\hline & $\pm \mathrm{SE}$ & 0.04 & 0.1 & 0.2 & 0.1 \\
\hline & $\mathbf{P}$ & & N.S & $<0.05$ & $<0.05$ \\
\hline \multicolumn{2}{|c|}{$\%$ Of change } & & -11.7 & 225 & 192 \\
\hline
\end{tabular}

Both groups of rats (exposed to noise or noise + drug)showed significant increase $(\mathrm{P}<0.05)$ when compared with control group(Table 3 ). 

Table (4): serum Total lipid level (mg/dl)in female albino rats after exposure to stress (noise) sulpiride , dual effect.

\begin{tabular}{|c|c|c|c|c|c|}
\hline \multicolumn{2}{|c|}{ Group } & control & drug & $\begin{array}{c}\text { Noise } \\
\text { alone }\end{array}$ & $\begin{array}{c}\text { Noise } \\
+ \text { +drug }\end{array}$ \\
\hline parameter & Mean & 197 & 195 & 210 & 203 \\
\hline \multirow{2}{*}{$\begin{array}{c}\text { Total lipid } \\
(\mathbf{m g} / \text { dl }\end{array}$} & \pm SE & 1.8 & 1.4 & 1.6 & 1.3 \\
\cline { 2 - 6 } & P & & N.S & $<0.01$ & $<0.05$ \\
\hline \multicolumn{2}{|r|}{$\%$ Of change } & & -1.0 & 6.5 & 3.0 \\
\hline
\end{tabular}

Table (4) noise exposure group was highly significant increase $(\mathrm{P}<0.01)$ and noise exposure and treated with sulpiride showed significant increase $(\mathrm{P}<0.05)$ when compared with control group.

Table (5): serum Triglycerides level(mg/dl) in female albino rats after exposure to stress ((noise) sulpiride , dual effect.

\begin{tabular}{|c|c|c|c|c|c|}
\hline \multicolumn{2}{|c|}{ Group } & control & drug & $\begin{array}{c}\text { Noise } \\
\text { alone }\end{array}$ & $\begin{array}{c}\text { Noise } \\
+ \text { drug }\end{array}$ \\
\hline \multirow{2}{*}{$\begin{array}{c}\text { Triglycerides } \\
(\mathrm{mg} / \mathrm{dl})\end{array}$} & Mean & 66.6 & 68.1 & 103.3 & 96.3 \\
\cline { 2 - 6 } & P & 1.5 & 1.2 & 1.6 & 1.7 \\
\cline { 2 - 6 } & & N.S & $<0.01$ & $<0.01$ \\
\hline \multicolumn{2}{|c|}{$\%$ Of change } & & 2.2 & 55.1 & 44.5 \\
\hline
\end{tabular}

Table (6): serum Cholesterol (mg/dl) level in female albino rats after exposure to stress (noise) sulpiride, dual effect.

\begin{tabular}{|c|c|c|c|c|c|}
\hline \multicolumn{2}{|r|}{ Group } & control & drug & $\begin{array}{c}\text { Noise } \\
\text { alone }\end{array}$ & $\begin{array}{c}\text { Noise } \\
\text { +drug }\end{array}$ \\
\hline \multirow{2}{*}{$\begin{array}{c}\text { Cholesterol } \\
(\mathrm{mg} / \mathrm{dl})\end{array}$} & \pm SE & 1.9 & 1.4 & 1.6 & 1.8 \\
\cline { 2 - 6 } & P & & N.S & $<0.01$ & $<0.01$ \\
\hline \multicolumn{2}{|r|}{$\%$ Of change } & & -2.6 & 43.4 & 11.7 \\
\hline
\end{tabular}


Table (7): serum HDL- Cholesterol level (mg/dl) in female albino rats after exposure to stress (noise) sulpiride , dual effect.

\begin{tabular}{|c|c|c|c|c|c|}
\hline parameter & Group & control & drug & $\begin{array}{l}\text { Noise } \\
\text { alone }\end{array}$ & $\begin{array}{l}\text { Noise } \\
+ \text { drug }\end{array}$ \\
\hline \multirow{3}{*}{$\begin{array}{c}\text { HDL- } \\
\text { Cholesterol } \\
(\mathbf{m g} / \mathbf{d l})\end{array}$} & Mean & 65.3 & 62.0 & 77 & 69.9 \\
\hline & $\pm \mathbf{S E}$ & 1.6 & 1.6 & 1.2 & 2.0 \\
\hline & $\mathbf{P}$ & & N.S & $<0.01$ & $<0.01$ \\
\hline \multicolumn{2}{|c|}{ \%Of change } & & -5.0 & 17.9 & $\mathbf{7 . 0}$ \\
\hline
\end{tabular}

Data represented in tables $(5,6,7,8)$ showed that (TG,HDL-C, LDL-C) levels of noise exposure group or noise exposure and treated with sulpiride recorded highly significant increase $(\mathrm{P}<0.01)$ of the (TG,HDL-C, LDL-C) level when compared with control group.

Table (8): serum LDL- Cholesterol (mg/dl) level in female albino rats after exposure to stress (noise) sulpiride, dual effect.

\begin{tabular}{|c|c|c|c|c|c|}
\hline \multicolumn{2}{|r|}{ Group } & control & drug & $\begin{array}{c}\text { Noise } \\
\text { alone }\end{array}$ & $\begin{array}{c}\text { Noise } \\
\text { +drug }\end{array}$ \\
\hline parameter & Mean & 51.1 & 49.2 & 91.4 & 60.1 \\
\hline $\begin{array}{c}\text { LDL- } \\
\text { Cholesterol } \\
(\mathrm{mg} / \text { dl) }\end{array}$ & \pm SE & 3.3 & 2.5 & 2.4 & 2.0 \\
\cline { 2 - 6 } & P & & N.S & $<0.01$ & $<0.01$ \\
\hline \multicolumn{2}{|r|}{$\%$ Of change } & & -3.7 & 0.8 & 17.6 \\
\hline
\end{tabular}

Regarding LDL/HDL -Cholesterol no significant change were recorded in all groups (table 9).

Table (9): serum LDL/ HDL- Cholesterol (mg/dl) level in female albino rats after exposure to stress (noise) sulpiride, dual effect.

\begin{tabular}{|c|c|c|c|c|c|}
\hline \multicolumn{2}{|r|}{ Group } & control & drug & $\begin{array}{c}\text { Noise } \\
\text { alone }\end{array}$ & $\begin{array}{c}\text { Noise } \\
\text { +drug }\end{array}$ \\
\hline parameter & Mean & 0.8 & 0.8 & 1.2 & 1.2 \\
\hline \multirow{2}{*}{$\begin{array}{c}\text { LDL/HDL- } \\
\text { Cholesterol } \\
(\mathbf{m g} / \text { dl) }\end{array}$} & \pm SE & 0.8 & 0.1 & 0.1 & 0.2 \\
\cline { 2 - 6 } & P & & N.S & N.S & N.S \\
\hline \multicolumn{2}{|r|}{$\%$ Of change } & & 0 & 0.5 & 0.5 \\
\hline
\end{tabular}


Drug treatment showed no detectable histological or histochemical changes in liver or kidney tissues with the exception of increased lymphocytes especially in the portal area of the kidney tissue.

Exposure of rats to noise showed several dystrophic changes in the kidney tissue compared with the control group (Fig. 1). These changes include: highly atrophied glomerulus's, faintly stained cells and nuclei of the convoluted tubules with wide lamina of the distal ones, ruptured brush borders of the proximal ones, thickened arterial walls with branched and corrugated walls of the congested vein. Kidneys of group noise + drug showed normal histological appearance .Increased collagen fibers were realized in the kidney tissue of noise group (Fig. 4) compared with the control group (Fig. 3). Also kidney tissue of group noise+ drug showed also increased collagen fibers in the convoluted tubules and Bowman $\square \mathrm{s}$ capsules (Fig. 5) .Kidney tissue of noise group showed poor stain affinity of PAS +ve materials in the haemolysed RBCs (Fig. 7) with moderately stained tunica media and adventitia of the highly distorted renal artery compared with the control group (Fig. 6) . Kidney of group noise+ drug showed normal stain affinity of PAS+ ve materials. Poorly stained glomeruli of the kidney cortex of noise group were detected, but some of them were atrophied and deeply stained (Fig. 9) compared with the control one (Fig. 8), also convoluted tubules were faintly stained .Drug treatment post- exposure to noise returned total protein to the normal level.

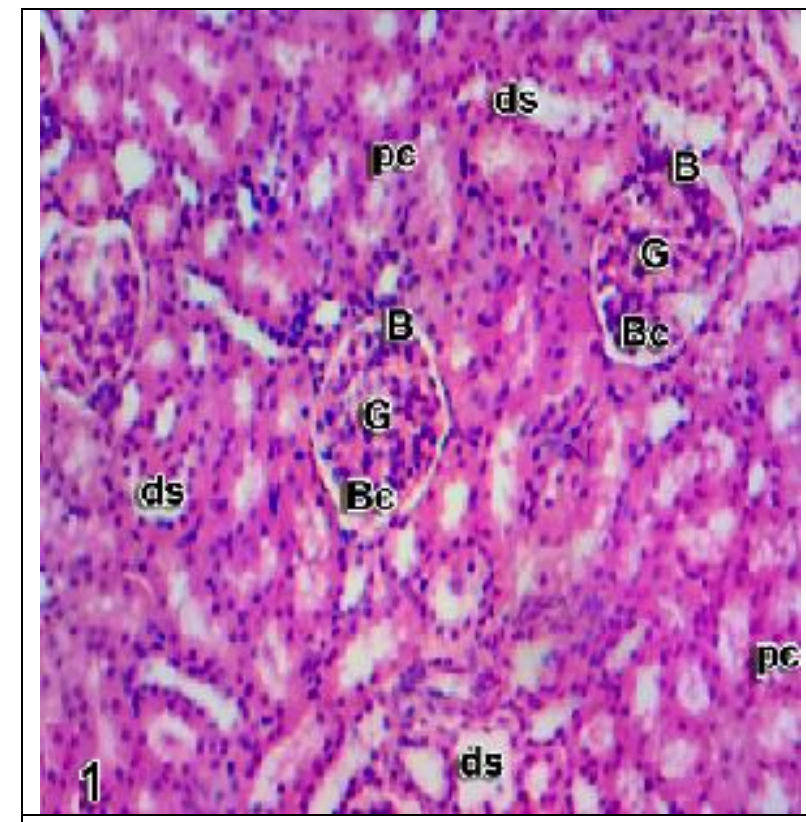

Photomicrograph of kidney tissue of control and treated rat

1-Showing kidney tissue of a control rat Notice. Malpighian's corpuscle with Bowman's capsule (B), Bowman's space (BC) glomeruli(G), distal convoluted tubules(ds) and proximal ones (pc).

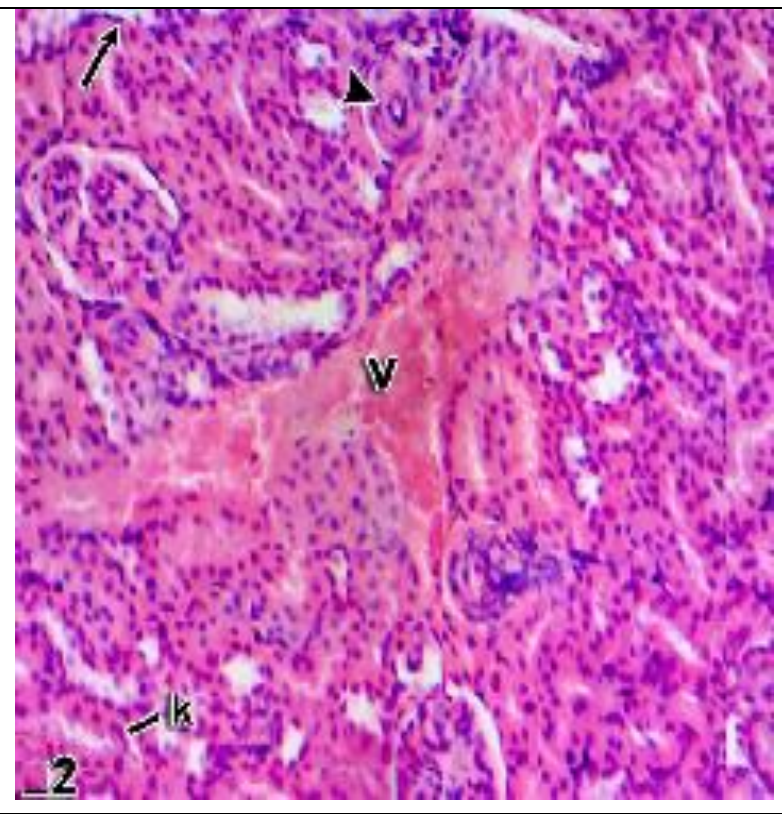

2-Showing kidney tissue of a rat exposed to noise stress.

Notice: many dystrophic changes which include: highly atrophied glomeruli (G) with many pyknotic nuclei $(\rightarrow)$, faintly stained cells and nuclei of the proximal and distal convoluted tubules, wide lumena of the distal convoluted tubules , ruptured brush border of the proximal highly thickened arterial wall with branched and corrugated wall of the congested vein $(\mathrm{V})$ $(\mathrm{Hx} \& \mathrm{Ex} 100)$ 



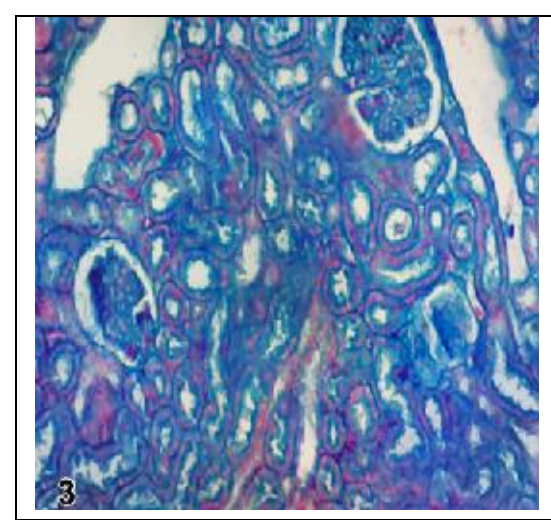

3: Showing thin collagen bundles supporting walls of the blood vessels, proximal and distal C.T, blood capillaries and Bowman's capsules of kidney tissue of a control rat.

(Mallory's trichrome stain x100)

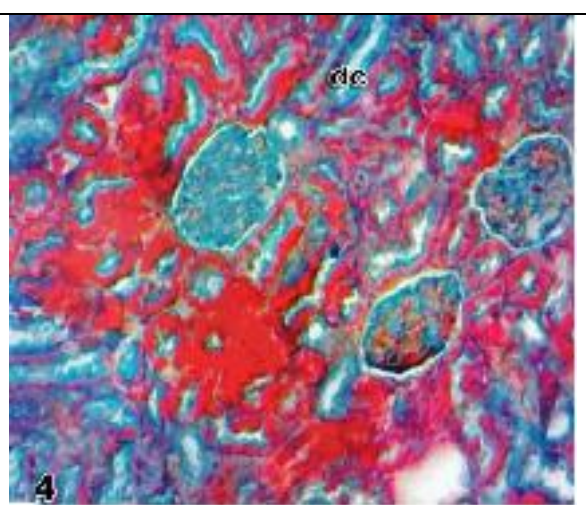

4: -Showing highly increased collagen fibers in the walls of the distal convoluted tubules (dc) and inside the glomeruli . Common fibrosis was detected in most proximal C.T and numerous brightly stained hemorrhagic areas in the kidney tissue of a rat exposed to noise stress. (Mallory's trichrome stain $\mathbf{x 1 0 0}$

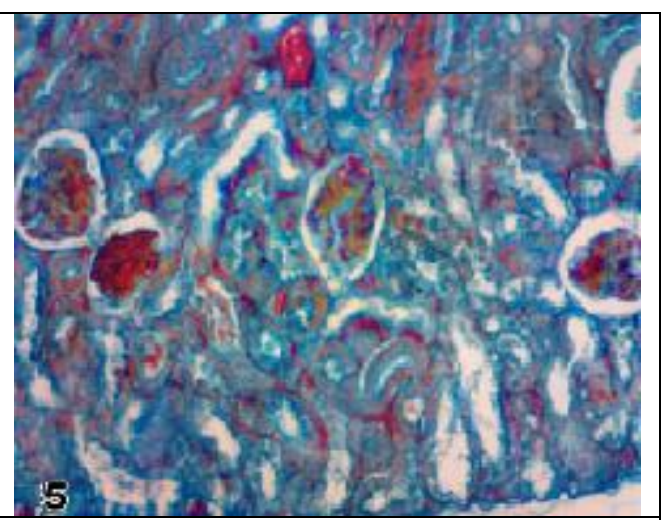

5: - Showing increased collagen fibers in between and around cells of the convoluted tubules and the Bowman's capsule of the kidney of a rat exposed to noise and treated with the drug.

(Mallory's trichrome stain x100)

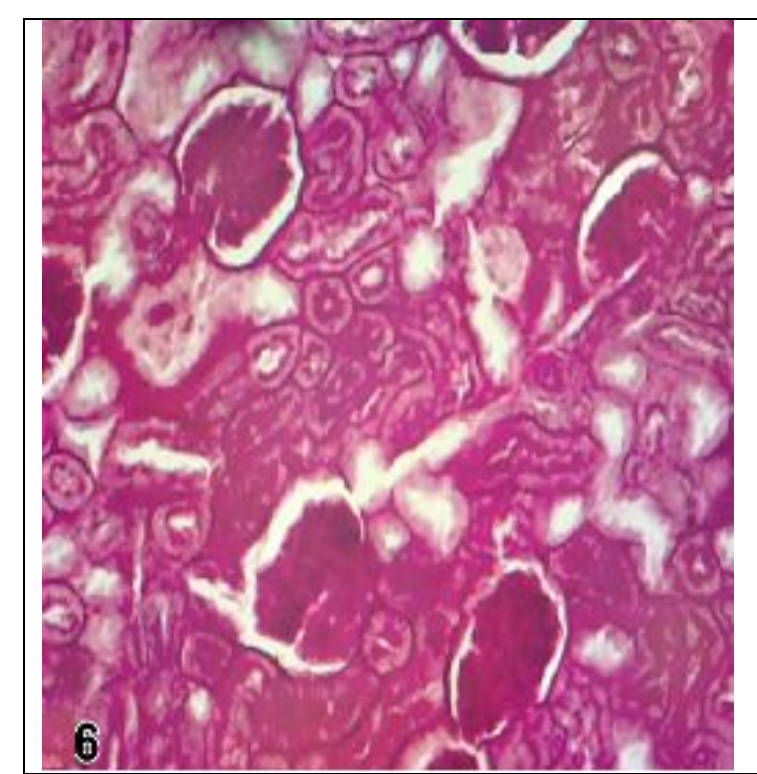

6- Showing normal distribution of polysaccharides in the kidney cortex of a control rat. deeply stained glomeruli, Bowman's capsules, brush border of The proximal C.T and cells of the distal C.T, but cells of the proximal ones were less stained. (PASx100) .

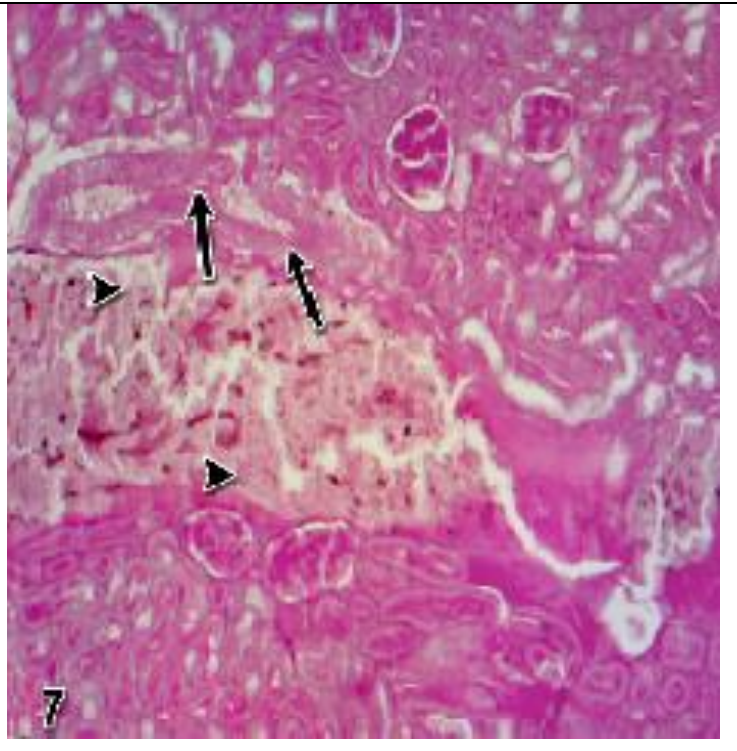

7: Showing distribution of polysaccharides in the kidney cortex of a rat exposed to noise. moderately stained tunica media and adventitia of highly elongated and distorted renal artery $(\rightarrow)$, faintly to moderately stained endothelial lining of the vein $(<)$ which contained poorly stained haemolysed RBCs. (PASx 100) 


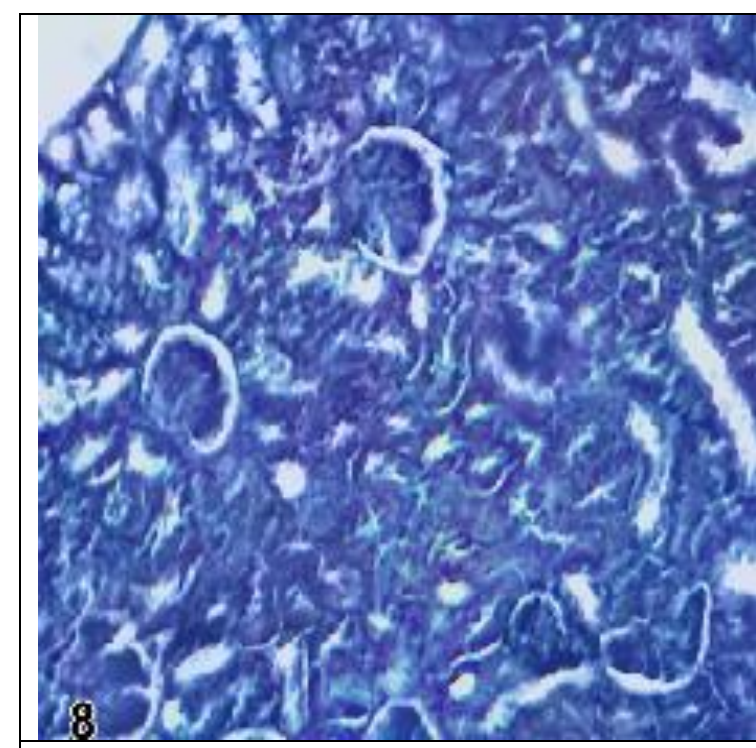

8: Showing normal distribution of total protein in the kidney tissue of a control rat.

Deeply stained glomeruli, cells of the proximal and distal convoluted tubules with less stained brush border. (Mercuric bromophenol blue x100)

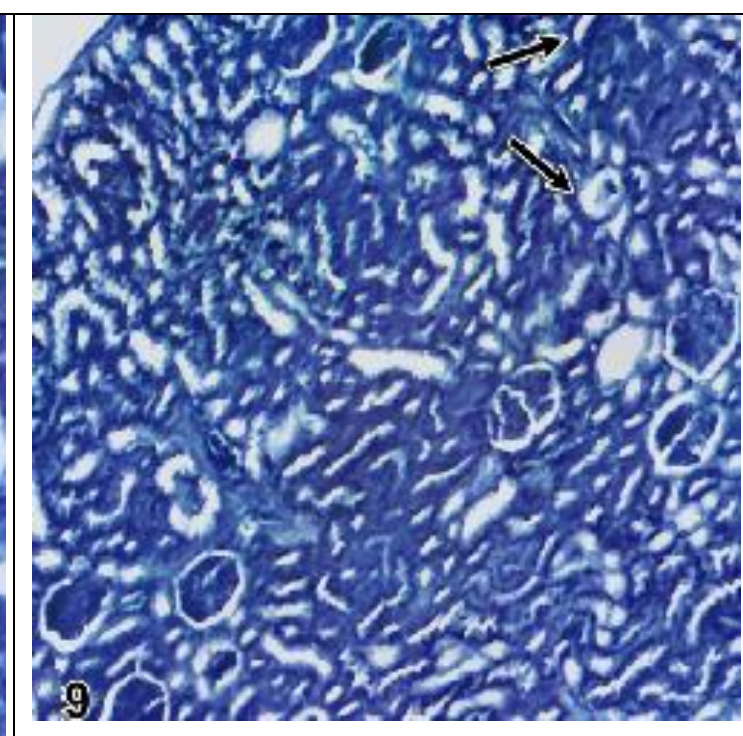

9: Showing total protein in the kidney tissue of a rat exposed to noise stress.

Some atrophied glomeruli were deeply stained, while some of them were poorly stained $(\rightarrow)$, some convoluted tubules were faintly stained.

(Mercuric bromophenol blue x100)

\section{Discussion}

\section{1-Kidney functions test:}

The present study showed significant increase $(\mathrm{p}<0.05)$ in serum creatinine in rat exposed to noise, noise+ drug. The abnormal out comes in the present study could have resulted from kidney function impairment such as generation in the poroximal convoluted tubules (Senior, 2009).

(Matsumoto et al., 2009) recorded an increase in creatinine serum in rat exposed to noise stress which may be due to increase catabolism in muscle and tissue that appear to act as a stimulus to synthesis of more serum creatinine.

According to Andrey(2010) noise stress causes hyperthyroidism which is one of the disease characterized by disturbances creatinine metabolism. Consequently it is of interest that hypothyroidism also associated with reduced kidney transamidinase activity. It may be that the effect of hyperthyroidism on kidney transamedinase is actually mediated by the increase level of blood creatinine which occur in the disease.

\section{2-lipid profile:}

The present results revealed that plasma lipid significantly increased when exposed to noise stress in adult female rats .Plasma lipid response to stress varies from stressor to other according to severity and combination of more than stressor (Willis et al.,2009) .The alteration in plasma lipid depends on the type and severity of stress as well as several individual characteristics, such as heightened neuroendocrine or autonomic reactively to stressors. So, stress may influence lipid concentration and metabolic thought variety of physiological and behavioral mechanisms (Blumenth et al,2000).

Radahmadi et al. (2006) demonstrated that all type of plasma cholesterol levels increased in response to stress particularly LDL-C which constitutes the bad type of cholesterol. Brenna et al. (1992) mentioned that stress induced increase in plasma level of cholesterol and triglyceride. Willis et al. (2009) mentioned that stress induced an elevation in serum total cholesterol concentration which may persist through the recovery period, increased triglyceride level, fatty acids, LDL-C and HDL-C.

The rate clearance of lipid also increases in some stressful situation. Meraihi et al.(1990) observed that Hyperlipidamia under noise stress may be due to decreased insulin secretion. Insulin has an 
antagonistic effect upon catecholamine mediated lipolysis . Sulpiride drug ameliorated the effect of noise of most measured parameter.

The histopathological and histochemical studies:

In 2008, Katzung stated that the sulpiride is a drug with relatively minor adverse effects .It has been regarded by some psychiatrists as the safest neuroleptic. Exposure of female rats to noise caused many deleterious changes in the kidney cortex. Highly thickened arterial walls were detected with haemolysed RBCs inside these arteries with numerous hemorrhagic areas in between the convoluted tubules .Increased kupffer cells and ruptured brush borders of proximal convoluted tubules with atrophied glomeruli were also observed. Hypertension is an established risk factor for congestive heart failure long-term exposure to pressure overload induces left ventricular remodeling and cardiac hypertrophy, subsequently resulting in heart failure (Zhang and Kaufman 2008). Reactive oxygen species (ROS) increased in response to mechanical stress, this increase in ROS induces apoptosis

( Katzung, 2008), and contributes to the progression of heart failure( Samson $\boldsymbol{e t}$ al .2005). Effects of noise on the immune status have also been reported (Archana and Namasivayam, 2000). Thus, noise exposure contributes to genesis and manifestation of several multifactor diseases, of chronic annoyance, and permanent behavioral alterations. According to Agarwal (2005) stresses led to oxidative stress which contributes to renal injury .This injury seems to be predominantly localized to the renal proximal tubules and this injury was realized in the destructed brush borders of proximal convoluted tubules observed in the present study. The previous results discuss the injury observed in the glomeruli and cells of proximal convoluted tubules in the kidney cortex of rats exposed to noise in the present study. Sings of improvement were observed in the kidney cortex of rats exposed to noise and treated with the drug, Zhang and Kaufman( 2008) declared that increased size and number of kupffer cells reflect clearly the active defense mechanism against the toxic substances and proliferation of the kupffer cells is achieved in order to engulf hepatic cell breakdown products. Normal distribution of collagen fibers was observed in the kidney cortex of control rats and those treated with the drug, but highly increased collagen fibers with common fibrosis were detected post exposure to noise. Increased collagen fibers observed in the present study may lead to rapid healing .This opinion was discussed by Zhang $\boldsymbol{e t}$ al . (2006) who reported that increased collagen may lead to rapid healing, rapid differentiation of cells and appearance of a new network of blood vessels, Increased collagen fibers were still noticed in kidney cortex of rats treated the drug and exposed to noise. Normal distribution of polysaccharides was observed in kidney cortex of rats treated with the drug compared with the control group, but some cells of convoluted tubules were less stained. Highly decreased polysaccharides were observed in the kidney cortex of rats exposed to noise this injury may be responsible for decreased total protein observed in the present study. Thickened and deeply stained arterial walls observed in the present study was also detected by another authors (Gu et al.,1998;Agrwal,2005) .They stated that exposure to stress induces oxidative stress and this leads to increased free radical production which cause hypertrophy in the vascular smooth muscle cells and hypertrophy of arterial walls and increased mortality . Decreased protein content due to oxidative damage has been reported by Nikolaos et al. (2004) and Samson et al .(2005) .

\section{References}

Agarwal M D ( 2005) : Hypertension in chronic kidney disease and dialysis : pathphysiology and management. Cardiol. Clin., 23: 237-248.

Andrey V (2010): Endoplasmic reticulum stress in proteinuric kidney disease Department of Medicine MCGill University Health centre.Montreal Quebec, Cananda. 77:187-193.

Archana $R$ and Namasivayam A (2000): Effect of Ocimum sanctum on noise induced 
change in neutrophil function, $\mathrm{J}$. Ethnopharmacol.,73: 81-85.

Blumenthal M, Busse W $\mathbf{R}$ and Goldberg A (2000): The Complete Commission monographs. Therapeutic guide to Herbal Medicnes .Boston ,M.A. Integrative medicines communication: 80-81

Brenna F X, Job R, Watkins $\mathbf{L} \mathbf{R}$ and Maier S F (1992): Total plasma cholesterol levels of rats are increased following only three sessions of tailshoch. Life-Sci., 50(13): 545-550.

Cleopatra S P (2007): Chronic restraint or variable stress differently affect the behavior, corticosteron secretion and body weight in rats. Physiology .Behavior Publishers: San Diego ,New York .90:29-102.

Drury $R$ and Wallinigton E (1980): Carleton's Histological Technique, $4^{\text {th }}$ Ed. Oxford. Univ. Press, New York, Toronto. Pp.:115-119.

Gu J W,Anand V and Shek E W (1998): Sodium induces hypertrophy of cultured myocardial myoblasts and vascular smooth muscle cell. Hypertension ,31:1083-7.

Junge W, Wilke B, Halabi A and Klein G (2004): Determination of reference intervals for serum creatinine, creatinine and creatinine clearance with an enzymatic and a modified taffe method Clin. Chim. Acta., 344: 137-148

Katzung B G (2008) : Basic and Clinic Pharmacology, Appleton \& Lange, Lepanon, , pp.: 448-460.

Knight J A, Anderson S and Rawie J M (1972): Chemical basies of sulfophosphovanilin reaction for estimation total serum lipid.Clin. Chem., 18:199-202.

Kytzia H (2005): Reference intervals for GGY according to the new IFCC $37^{\circ} \mathrm{C}$ reference procedure. abstracts: Congress of Clinical Chemistry and Laboratory Medicine, 103: 6-8.

Matsumoto S, Hanai $H$.Matsuura $H$ and Akiyama Y (2009): Creatol, an oxidative product of creatinine in kidney transplant patients, as a useful determination of renal function : A, preliminary study. Transplantation Proceedings,38:2009-2011.

Mazia D, Brewer P and Alfert M (1953): The cytochemical staining and measurement of protein with mercuric bromophenol blue .Biol.Bull.,104: 57-67.

Meraihi Z, Lutzo O, Scheftal J $M$ and Bach A C (1990) : Decreased lipolytic activity in tissue during infection and inflammatory stress. Nutrition, 7(2) : 93-98.

Nikolaos $\mathbf{P}$, George $Z$, Nikolaos $T$ P,Christos D G , Fevronia A and Nikolaos A M (2004): Thiol redox state (TRS) and oxidative stress in the mouse hippocampyus after pentylenetetrazol - induced epileptic seizure. Neurosci. Lett., 357: 83-86.

Paget G $\mathbf{E}$ and Barnes $\mathbf{J} \quad \mathbf{M}$ (1964):Evaluation of drug activity in Pharmaceutics Laurence and Bacharach eds ., Vol.1 Academic press. NewYork.

Panzani D I ,Zicchino a and Taras P (2011): Sulpiride use of dopamine antagonist sulpiride to advance first ovulation in transitional mares .Theriogenology, 75: 138-143.

Pearse A (1977) : Histological Theoretical and Applied $3^{\text {th }}$ ed vol I.Churchill Livingstone ,London 112-115 .

Radahmadi M, Shadan F, Seied $M$ and Nasmimi A (2006): Effects of stress on exacerbation of diabetes mellitus, serum glucose and cortisol levels and body weight in rats Pathophysiology, 311: 51-55.

Samson T, Sheela D, Ravidran $M$ and Senthilvelan A (2005): Effect of noise stress on free radical scavenging enzymes in brain. Environmental toxicology and pharmacology, 20:142-148.

Senior R (2009): Stress Test for the Kidney . Department of Nephrology All India institute of Medical Sciences New Delhi. 110-129.

Snedecor G W and Cochran W G (1980): Statistical Method .United State University Press,Lowa, London Pp: 59-60.

Stein E A and Myers G L (1995): National cholesterol education program recommended for triglycerides measurement. Ameta-analysis of 27 trials.Arterioscler. Thromb., 41: 14211426.

Sugiuchi (2005): History of development and technical details of the homogenous assay for HDL and LDL cholesterol .Eng .J.Med., 1: 411.

Tietz, N.W. (1995): Clinical Guide to Laboratory Tests. 3ed ${ }^{\text {rd }}$ Philadelphia Pa: W.B. Saunders Company Londan , Pp: 130-131.

Tietz, N.W. (2006): Clinical Guide to Laboratory Tests. Chemistry Saunders Co., London $4^{\text {th }}$ ed. Pp : 44-51.

Tomoyuki H (2004): The effect of noise on the health of children. J. Nippon. Med. School, 71:5-10.

Wiilis C,Armario A, and Piganini $\mathrm{H}$ (2009): Cholesterol and triglyceride concentration in rat plasma after stress .Pharmacol .Biochem.Behav.,31(1):75-79.

Zhang $K$ and Kaufman $R$ J (2008): From endoplasmic -reticulum stress to the inflammatory response .Nature , 454: 455-462.

Zhang D, Xu Z, Chiang A, Lu D and Zeng Q (2006): Effect of GSM $1800 \mathrm{MHz}$ radiofrequency EMF on DNA damage in Chinese hamuster lung cells. Zhonghuo Nei. Ke. Za. Zhi., 36(3): 183-186. 


\section{تأثير الضوضاء و العلاج بعقار السلبرايد على بعض المعايير الفسيولوحية والههتولوجية فى إناث الجرذان البلان البيضاء}

\section{إيمان جمال الاين عزت هلال, فاطمة عيد و نعمة محمود طها عطية}

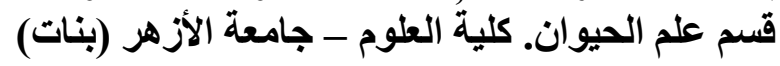

يعتبر الضوضاء من أكثر المؤثرات العصبية على الإنسان لذا تهدف هذه الدراسة إلى توضيح آثارها على بعض المعايير الفسيولوجية و الهستولوجية وتمت هذه الدراسة على إناث الجرذان التى قسمت إلى أربع مجمو عات( 7 \ مجموعة) وكانت كالتالى . المجمو عة الأولى:- استخدمت كمجموعة ضابطة . المجمو عة الثانية :- مجمو عة عولجت بعقار السلبر ايد فقط. المجموعة الثالثة :-مجموعة الجرذان التى تعرضت للضوضاء فقط يوميا لمدة.ب يوما أكثر من • 9 ديسبل المجموعة الرابعة : مجموعة الجرذان التى تعرضت للضوضاء وعولجت بعقار السلبر ايد. ولقد أوضحت نتائج هذا البحث أن المعالجة بعقار السلبرايد لم يحدث أى تغير فى كل المعايير التى تم در استها. أما عند التعرض للزحام فقد كانت هناك زيادة إحصائية فى كل من : وظائف الكلى_البروتين الكلىو الدهون الكلية و الثثلاثية والكولسترول عالى الكثافةو الكولستيرول منخفض الكثافة ولقد إتضح أن هذا العقار حسن الكثير من التغير ات الناتجةعن الضوضاء .لوحظ أن تعاطى عقار السلبر ايد لم يظهر أى أثار جانبيه فى نسيج الكلى ولكن لوحظت زيادة فى الخلايا اللمفية أما التعرض للضوضلاء فقط أظهرتغير ات هستولوجية وكميانسيجية عديدة بالنسيج الكلوى وأظهرت المعاملة بالعقار بعد التعرض للضوضاء تحسنا ملحوظا فى كل النسيج الكلوى. ولهذا ينصح باستخدام عقار السلبر ايد فى البشر الذين يتعرضون للضوضاء. 
Eman Helal....et al 